\title{
PENGARUH STORE ATMOSPHERE, BRAND AMBASSADOR DAN GREEN MARKETING TERHADAP MINAT BELI KONSUMEN INNISFREE CENTRAL PARK MALL
}

\author{
Ananda Nasyatul K ${ }^{1}$, Subagyo *) \\ *) Dosen Tetap FEB Universiats SatyaNegara Indonesia Jl.Arteri Pondok Indah No.11 Jakarta \\ E-mail: ananda.nasyatul25@gmail.com,bagyolink@,cbn.net.id
}

\begin{abstract}
This study aims to determine the effect of Store Atmosphere, Brand Ambassadors and Green Marketing on Consumer Purchase Interest at Innisfree Central Park Mall. The method used in this study is a quantitative method and the results of the study are based on respondents' answers using a Likert scale. The population in this study is Innisfree Central Park Mall consumers, the sample in this study amounted to 100. Data analysis methods used in this study are Multiple Linear Regression Test, $f$ Test, $t$ Test and Determinant Coefficient. The results showed that simultaneously (f test) showed that there was a significant influence between the Store Atmosphere (XI), Brand Ambassador (X2) and Green Marketing (X3) variables on Consumer Purchase Interest (Y). partially (Test $t$ ) Store Atmosphere does not significantly influence Consumer Purchase Interest and Brand Ambassador has no significant effect on Consumer Purchase Interest, while Green Marketing has a significant effect on Consumer Purchase Interest.
\end{abstract}

\section{Keywords: Store Atmosphere, Brand Ambassadors, Green Marketing and Consumer Purchase Inntention.}

\section{PENDAHULUAN}

Kecenderungan seseorang untuk membeli suatu produk didasari pada suatu pola hidup masyarakat yang konsumtif. Menurut Michael R Solomon (2013) perilaku konsumtif adalah proses pembelajaran yang melibatkan seseorang atau kelompok ketika memilih, membeli menggunakan atau menempatkan suatu produk, jasa ide atau pengalaman untuk memuaskan kebutuhan dan keinginan. Sebagai akibatnya mereka kemudian membelanjakan uangnya dengan membabi buta dan tidak rasional, sekedar untuk mendapatkan barang-barang yang menurut anggapan mereka dapat menjadi simbol keistimewaan. Perilaku konsumtif biasanya terjadi pada remaja, Menurut Triyan Pangastuti (2018) perilaku konsumtif sudah mempengaruhi pada remaja kita. Pasalnya, produsen melihat usia remaja adalah pasar potensial mereka. Mereka paham pada usia remaja, sangat mudah tergiur dengan iklan yang menarik dan membuat remaja ingin memilikinya. Kebiasaan berbelanja tidak bisa lepas dari kehidupan seseorang untuk memenuhi kebutuhannya, Menurut Nugroho J. Setiadi (2013:22) manusia akan selalu dihadapkan pada persoalan kebutuhan hidup, baik itu kebutuhan primer, sekunder maupun tersier. Pemenuhan kebutuhan hidup selalu dikaitkan pada persoalan pengorbanan atau yang dikenal dengan biaya yang akan dikeluarkan untuk mendapatkan sesuatu yang dibutuhkan.

Seiring perkembangan zaman kosmetik telah menjadi kebutuhan primer bagi sebagian kaum wanita, karena kosmetik dianggap menjadi bagian dari kehidupan sehari-harinya demi mempertahankan kecantikan. Dahulu Kosmetik adalah suatu produk make up yang digunakan pada acara-acara formal tetapi dengan seiringnya zaman make up sudah tidak hanya digunakan untuk acara formal saja tetapi menjadi penunjang kegiatan sehari-hari seperti pada suatu pekerjaan. Menurut penelitian NPD, Insight Into The Youth Beauty Market (2009), para remaja dan perempuan muda menjadi berkurang ketergantungannya terhadap kecantikan dan kosmetik. Akan tetapi, anak-anak remaja justru semakin tergila-gila memakai make up. Menurut data dari lembaga riset NPD Group sepanjang tahun 2007-2009 bahwa penggunaan maskara, eyeliner dan lipstik oleh 
anak-anak remaja ternyata bertambah dua kali lipat dari tahun-tahun sebelumnya. Maka dengan bergesernya pola hidup tersebut produsen kosmetik saat ini berlomba-lomba membuat produk kosmetik ramah dengan kalangan remaja, seperti membuat produk kosmetik dengan bahan yang aman bagi kulit remaja, membuat desain menarik pada produk mereka, dan melakukan promosipromosi yang menarik minat kalangan remaja.

Kementrian Perindustrian menargetkan pertumbuhan industri kosmetik tahun 2019 mencapai 9\% meningkat dibanding target pertumbuhan tahun lalu sekitar 7,3\%. Hal ini antara lain dipicu oleh meningkatnya trend kebutuhan masyarakat terhadap produk kecantikan dan perawatan tubuh. Pemerintah optimis, industri kosmetik dalam negeri tak hanya tumbuh di pasar dosmetik, tapi juga di pasar dunia. Menurut Achmad Sigit Dwiwahjono (2019) Direktur Jenderal Industri Kimia, Farmasi dan Tekstil Kementrian Perindustrian "kami menargetkan pada tahun ini, industri kosmetik dapat tumbuh hingga 9\%". Produk kosmetik di Indonesia terus mengalami peningkatan dengan adanya pergeseran pola hidup yang dimana kosmetik digunakan tidak hanya pada perempuan muda saja tetapi anak-anak remaja. Dengan peningkatan permintaan kosmetik di Indonesia, hal ini mendorong banyaknya industri kosmetik harus terus bersaing dalam menciptakan produk dengan keunggulan-keunggulan yang dimiliki oleh masing-masing perusahaan tersebut untuk menarik minat beli konsumen. Hal ini membuat banyak sekali merek kosmetik yang beredar di pasaran mulai dari brand local maupun brand internasional. Berikut adalah merek kosmetik yang sering beredar dipasar Indonesia.

Tabel 1.1

Merek kosmetik yang ada di pasar Indonesia

\begin{tabular}{|c|c|c|c|c|c}
\hline No & Merek Kosmetik & Asal Negara & No & Merek Kosmetik & Asal Nega \\
\hline 1. & PAC & Indonesia & 8. & The Body Shop & UK \\
\hline 2. & Sari Ayu & Indonesia & 9. & Maybelline & US \\
\hline 3. & Caring Colours & Indonesia & 10. & Make Up Forever & Fance \\
\hline 4. & Wardah & Indonesia & 11. & Innisfree & South Korc \\
\hline 5. & Inez & Indonesia & 12. & Nature Republic & South Kor \\
\hline 6. & Mustika Ratu & Indonesia & 13. & Silky Gril & Malaysia \\
\hline 7. & \multicolumn{2}{|c|}{ Indonesia } & 14. & Ultima II & US \\
\hline
\end{tabular}

Berdasarkan pada Tabel 1.1 persaingan merek kosmetik yang ada di pasar Indonesia terdapat beberapa brand yang sering diminati oleh wanita Indonesia. Tidak hanya pada brand local saja tetapi brand internasional saat ini sedang digandrungi oleh wanita Indonesia. Menurut Putri Syifa Nurfadilah (2018) Produk yang paling difavoritkan di Indonesia justru bukan produk dalam negeri, melainkan produk asal Korea Selatan. Data dari survei Beauty Index 2018 terhadap 17.889 perempuan mengungkapkan, sebanyak $46,6 \%$ perempuan menyukai produk asal negeri gingseng. Diikuti 34,1\% yang memfavoritkan produk asal Indonesia, lalu 21,1\% memilih produk asal Jepang. Yasanova Savitry (2018) mengatakan "kecenderungan konsumen kecantikan Indonesia saat ini lebih menjadikan Korea Selatan sebagai kiblat dan produk yang saat ini jadi trend adalah produk dari Korea Selatan seperti Laneige, Nature Republic dan Innisfree".

Innisfree adalah sebuah brand asal Korea Selatan yang bergerak dalam bidang kosmetik dan perawatan kulit yang berbahan dasar alami dan organik. Pada tahun 2000 adalah peluncuran Innisfree sebagai brand Korea pertama yang berkonsep natural. Pada 2017 Innisfree membuka store pertamanya di Indonesia tepatnya di Central Park Mall. Innisfree mengeluarkan produk kosmetik dari wajah, bibir, mata, kuku hingga alat kecantikan untuk menunjang hasil make up yang bagus.

Ditengah banyaknya kebutuhan dan keinginan yang beragam dari konsumen, maka Innisfree menambah inovasi-inovasi yang unik dalam rangka memikat konsumen untuk ber-minat membeli produk tersebut. Minat beli yang biasanya terjadi pada konsumen dimotivasi oleh promosi dan motif emosional. Salah satu contoh adalah minat beli yang dipengaruhi oleh Brand Ambbasador, Green Marketing dan Store Atmosphere. Suatu produk yang ditawarkan oleh salah 
satu public figur terkenal akan memudahkan produk itu dapat diminati oleh konsumen, begitupun juga green marketing yang dilakukan Innisfree membawakan tema hijau seperti sea water dan green tea. penampilan toko yang menarik dengan desain yang unik dan warna-warna hijau akan membuat mata konsumen tertarik mengunjungi toko tersebut dan memikirkan untuk membeli suatu produk.

Upaya yang dilakukan oleh Innifree ternyata tidak segaris dengan minat beli yang ditunjukkan oleh fakta pada tabel 1.2 dalam rekapitulasi pengunjung pada store Innisfree Central Park Mall periode 2 Februari 2020 - 14 Maret 2020.

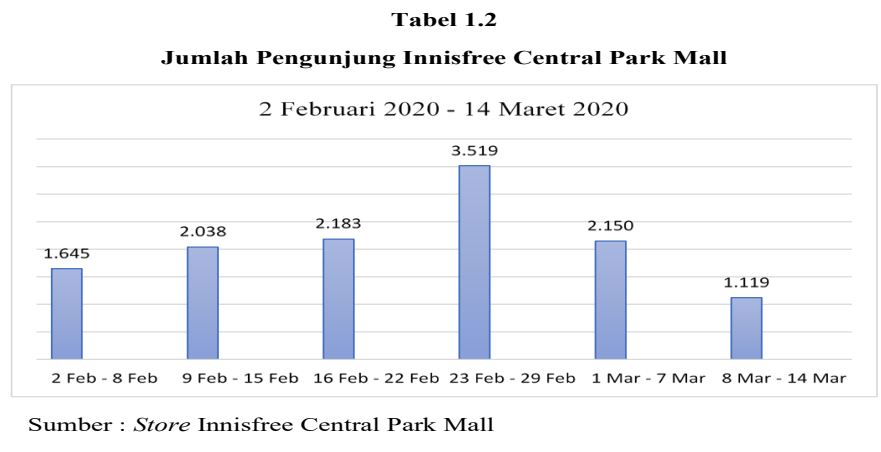

Pada Tabel 1.2 diatas dapat kita lihat bahwa minat kunjung pada store Innisfree Central Park Mall masih terjadi fluktuasi dalam kurun waktu 3 bulan ini. Hal ini tentunya berkaitan dengan minat beli konsumen di store tersebut yang berkolerasi dengan keputusan pembelian dan penjualan. Dalam konsep pemasaran terdapat AIDA (attention, interest, desire and action). Hal ini tentunya berkaitan dengan jumlah penjualan pada store Innisfree yang ditunjukkan melalui presentase penjualan pada tabel berikut.

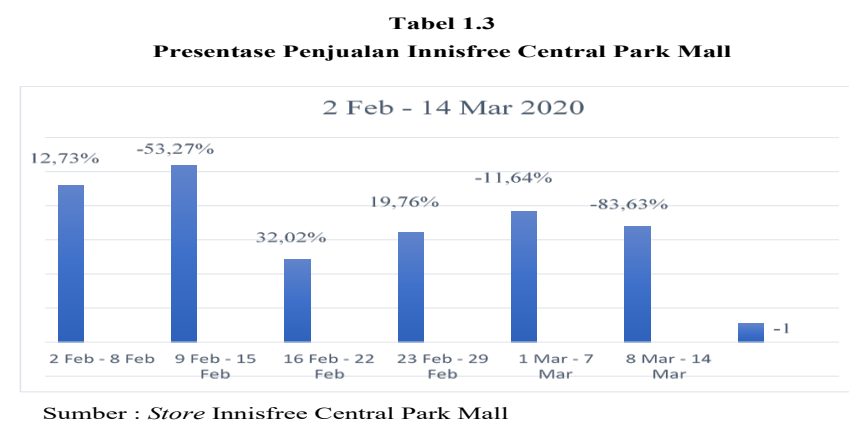

Dari dua data tersebut terdapat perbedaan pada jumlah pengunjung dengan keputusan pembelian konsumen. Hal ini dapat dilihat pada tabel 1.2 dan tabel 1.3 yang dimana pengunjung dengan frekuensi tertinggi belum tentu berpengaruh pada keputusan pembelian konsumen.

Untuk itu manajemen Innisfree melakukan berbagai strategi agar konsumen berminat mengunjungi store. Beberapa strategi yaitu mempertahankan kualitas produk seperti; produknya yang tetap konsisten menggunakan bahan-bahan yang alami. Dalam hal mengembangkan citra merek Innisfree juga menarik minat konsumen dengan cara penguatan merek melalui promosi dengan memberikan bonus-bonus yang menarik setiap pembelian produk. Innisfree juga melakukan peremajaan store atmosphere dengan layout dan desain yang minimalis, menggunakan brand ambbasador yang menjadi role mode dalam kehidupan wanita saat ini serta menerapkan green marketing yaitu dengan melakukan kegiatan sosial mengenai lingkungan. Strategi manajemen diharapkan sudah sangat baik dalam menarik minat beli konsumen. Namun hal ini menjadi fenomena karena pada kenyataannya jumlah pengunjung pada store Innisfree Central Park Mall tidak segaris dengan tingkat penjualan, untuk itu perlu kajian apakah strategi pemasaran yang 
dilakukan melalui store atmosphere, brand ambassador dan green marketing sudah sesuai. Apakah Strategi tersebut dapat mempertahankan bahkan meningkatkan minat beli konsumen.

Store Atmosphere meliputi berbagai tampilan interior, exsterior, tata letak, lalu lintas internal toko, kenyamanan, udara, layanan, musik, seragam, pajang barang dan sebagainya yang menimbulkan daya tarik bagi konsumen dan membangkitkan keinginan untuk membeli. Menerut Berman dan Evan yang dialih bahasakan Lina Salim (2014:528).

Brand Ambassador adalah individu yang terkenal oleh publik atas prestasinya selain dari pada produk yang didukungnya penggunaan brand ambassador dimaksudkan untuk memberikan dorongan kepada pesan iklan agar lebih mudah diterima oleh konsumen dan mempermudah tumbuhnya keyakinan konsumen atas produk yang diiklankan oleh karena itu brand ambassador harus memiliki pengaruh positif untuk meningkatkan minat beli pada suatu produk. menurut Kertamukti (2015:71). Brand Ambassador dirasa efektif dalam menarik minat beli konsumen karena masyarakat Indonesia memiliki kecenderungan mengikuti gaya hidup public figur dari fashion, sesuatu yang sedang happening, sampai pada penggunaan kosmetik. Maka tak jarang sebuah produk berlomba-lomba menggunakan public figur yang saat ini menjadi role mode kehidupan orang Indonesia untuk menarik minat beli pada konsumen.

Strategi yang dilakukan Innisfree terkait brand ambassador adalah memilih wanita muda yang saat ini menjadi role mode oleh wanita Indonesia. Innisfree menggunakan Yoona sebagai brand ambassador-nya. Wanita kelahiran 1990 ini melambung namanya karena bergabung dalam girl band yang banyak disenangi oleh wanita-wanita Indonesia saat ini yaitu SNSD. Dengan penampilan wajahnya yang sangat cantik dan alami membuat Yoona dipilih Innisfree untuk menjadi brand ambassador sejak tahun 2009 sampai saat ini.

Green Marketing adalah pertimbangan lingkungan yang diintegrasikan ke dalam semua aspek pemasaran, pengembangan produk, proses produksi, pengemasan serta modifikasi iklan, dengan pendekatan marketing mix (produk, price, place, promotion) dan theory of planned behaviour terhadap environmental concern dan green marketing consumerism. Menurut Allen Manongko (2018:32). Strategi yang dilakukan Innisfree adalah membuat produk berbahan dasar alami, Innisfree selalu aktif dalam kegiatan sosial dan kampanye tentang lingkungan seperti penggunaan sapu tangan untuk menggantikan kebiasaan wanita Indonesia yang membersihkan make up nya dengan kapas. Yoona selaku brand ambbasador kerap mengikuti kampanye dan mempromosikan sapu tangan ramah lingkungan yang dibuat oleh Innisfree dengan merilis lagu berjudul "Innisfree Day" pada tahun 2010 dan peluncuran re-cycle botol kosong. Pada era saat ini kepedulian akan lingkungan dirasa meningkat khususnya pada anak muda, mereka banyak membuat kegiatan untuk melestarikan alam, dari mengurangi penggunaan plastik, kertas sampai menjaga alam sekitar. Hal ini menjadi strategi Innisfree dalam meningkatkan minat beli konsumen karena kegiatan anak muda tentang lingkungan sejalan dengan konsep yang dibangun Innisfree yaitu natural.

\section{LANDASAN TEORI \\ Minat Beli Konsumen}

\section{Pengertian Minat Beli}

Minat beli menurut Kotler, Bowen dan Makens (2014) timbul setelah adanya proses evaluasi alternatif. Di dalam proses evaluasi, seseorang akan membuat suatu rangkaian pilihan mengenai produk yang hendak dibeli atas dasar merek maupun minat. Sedangkan menurut Morissan (2014:84) minat beli adalah tahap dari keputusan pembelian dimana suatu titik dalam proses pembelian, konsumen harus berhenti melakukan evaluasi, konsumen mulai mengarah pada minat beli dan keinginan untuk membeli dengan kecenderungan untuk membeli merek tertentu. Sedangkan menurut Assel dalam Donni Juni Priansa (2017:163) minat pembelian adalah bentuk kecenderungan dari seorang konsumen untuk mengambil tindakan dalam hal pembelian sebuah produk dari sebuah perusahaan, yang dapat diukur dengan melakukan pembelian pada keputusan akhir. 
Berdasarkan teori-teori yang dikemukakan maka dapat diambil kesimpulan bahwa minat beli adalah suatu keinginan terhadap pilihan produk yang didasari merek, biasanya dilalui dengan proses evaluasi sampai berhenti melakukan evalusi dengan proses akhir mengambil tindakan pembelian.

\section{Tahapan Minat Beli}

Kotler dan Keller dalam Donni Juni Priansa (2017:164) menyatakan tahapan minat beli dari seorang konsumen dapat dilihat dan dipahami melalui model AIDA (attention, interest, desire dan action). Berikut merupakan pengertian dalam AIDA untuk memahami tahapan minat beli:

a) Attention

Pada tahap ini dilakukan penilaian terhadap suatu produk oleh seorang konsumen, apakah sesuai dengan kebutuhan serta keinginannya, konsumen akan berusaha lebih mengenal produk yang ia anggap potensial untuk dibeli. Attention merupakan tahap paling awal dalam tahapan minat pembelian konsumen terhadap suatu produk.

b) Interest

Konsumen akan mulai memiliki ketertarikan lebih terhadap suatu produk setelah melakukan penilaian serta mendapatkan cukup pengetahuan dan informasi tentang produk yang menarik perhatiannya.

c) Desire

Setelah hasrat serta keinginan konsumen mulai timbul terhadap suatu produk maka konsumen konsumen mulai berfikir dan berdiskusi akan produk yang ditawarkan. Dalam tahap ini minat terhadap produk sudah kuat serta konsumen yakin akan produk atau jasa yang ditawarkan oleh perusahaan.

d) Action

Action merupakan tindakan akhir yang dilakukan oleh seorang konsumen untuk membeli produk yang ia butuh dan inginkan. Pada tahap ini konsumen telah benar-benar yakin untuk melakukan pembelian.

Salomon juga berpendapat bahwa tahapan dalam minat beli konsumen dapat dipahami dengan tiga tahap model CAB (Cognitive, Affect dan Behaviour). Cognitive merupakan gambaran pengetahuan dan persepsi konsumen terhadap suatu produk barang atau jasa, sedangkan Affect adalah perasaan serta emosi konsumen terhadap brand tertentu dan behaviour adalah kecenderungan konsumen dalam melakukan tindakan tertentu yang berkaitan dengan produk maupun jasa.

\section{Faktor-Faktor yang Mempengaruhi Minat Beli}

Faktor yang berpengaruh terhadap minat beli konsumen erat kaitannya dengan perasaan emosi seorang konsumen. Menurut Swastha dan Iarawan menyatakan bahwa perasaan senang dan puas konsumen ketika membeli suatu produk berupa barang maupun jasa akan memperkuat minat beli. Sebaliknya, konsumen yang merasa kecewa terhadap suatu produk tentu minat beli terhadap produk tersebut berkurang bahkan bisa hilang. Jika konsumen tidak mengenal dan menyadari akan kebutuhan dan keinginannya maka tidak akan ada kegiatan pembelian terhadap suatu produk

\section{Dimensi dan Indikator Minat Beli}

Menurut Donni Juan Priansa (2017:164), minat beli dapat diidentifikasi melalui indikatorindikator sebagai berikut.

a) Minat transaksional, yaitu kecenderungan seseorang yang selalu ingin membeli produk atau jasa yag ditawarkan oleh perusahaan. dalam hal ini biasanya mencangkup ketertarikan pada suatu produk, keinginan untuk membeli dan harga suatu produk.

b) Minat Refrensial, yaitu kecenderungan seseorang untuk mereferensikan produk kepada orang lain. Dalam hal ini biasanya mencangkup membicarakan suatu produk tersebut, mengatakan hal positif terkait produk dan produk akan direferensikan.

c) Minat Prefensial, menggambarkan perilaku konsumen yang mempunyai prioritas atau prefensi utama terhadap suatu produk yang dianggap layak. Hal ini mencangkup menggunakan produk 
diwaktu mendatang, keinginan menggunakan produk secara terus-menerus dan tidak menggunakan produk lainnya.

d) Minat eksploratif, minat ini menggambarkan perilaku seseorang yang selalu mencari informasi mengenai produk yang diminatinya dan mencari informasi untuk sifat-sifat positif dari produk tersebut. hal ini berkaitan dengan mencari informasi terbaru mengenai produk, mencari informasi promosi produk dan membeli produk untuk sebuah bahan perbandingan.

\section{Store Atmosphere}

\section{Pengertian Store Atmosphere}

Store atmosphere menurut Kotler dan Keller yang dialih bahasakan oleh Bob Sabran (2013:69) adalah suasana terencana yang sesuai dengan pasar sasarannya dan yang dapat menarik pelanggan untuk membeli. Sedangkan menurut Gillbert (2013:129) store atmosphere merupakan kombinasi dari pesan secara fisik yang telah direncanakan. Suasana toko dapat digambarkan sebagai perubahan terhadap perencanaan lingkungan pembelian yang menghasilkan efek emosional khusus yang dapat menyebabkan konsumen melakukan tindakkan pembelian. Sedangkan menurut Berman dan Evan yang dialih bahasakan Lina Salim (2014:528)

store atmosphere meliputi berbagai tampilan interior, ekterior, tata letak, lalu lintas internal toko, kenyamanan, udara, layanan, musik, seragam, pajang barang dan sebagainya yang menimbulkan daya tarik bagi konsumen dan membangkitkan keinginan untuk membeli.

Dari beberapa teori yang dikemukakan dapat diambil kesimpulan bahwa store atmosphere adalah tampilan toko secara terencana yang mempengaruhi efek emosional dan daya tarik untuk menarik pelanggan melakukan tindak pembelian.

\section{Faktor-Faktor yang Menciptakan Store Atmosphere}

Beberapa faktor yang berpengaruh dalam menciptakan suasana toko menurut Lamb, Hair dan McDaniel (2014:256), yaitu:

a) Jenis karyawan, karakteristik umum karyawan, sebagai contoh: kerapihan, keramahan, berwawasan luas, atau berorientasi pada pelayanan.

b) Jenis produk dan kepadatan, jenis produk yang dijual bagaimana produk tersebut dipajang menentukan suasana yang ingin diciptakan oleh produsen.

c) Jenis perlengkapan tetap dan kepadatan, perlengkapan tetap bisa elegan dan trendi. Perlengkapan tetap harus konsisten dengan suasana umum yang ingin diciptakan. Contoh: menciptakan suasana santai dan teratur dengan meja dan rak, memungkinkan pelanggan lebih mudah terlihat, dan menyentuh produk dengan mudah.

d) Bunyi suara, bunyi suara bisa menyenangkan atau menjengkelkan bagi seorang pelanggan. Musik juga bisa membuat konsumen tinggal lebih lama di toko. Musik dapat mengontrol lalu lintas di toko, menciptakan suasana citra dan menarik atau mengarahkan perhatian pembelinya.

e) Aroma, bau bisa merangsang maupun mengganggu penjualan.

f) Faktor visual, warna dapat menciptakan suasana hati atau memfokuskan perhatian. Pencahyaan juga dapat mempunyai pengaruh penting pada suasana toko.

\section{Dimensi dan Indikator Store Atmosphere}

Berman dan Evan (2014:545) terdapat elemen store atmosphere yang terdiri dari exterior, general interior, store layout dan interior display:

a) Store exterior adalah bagian depan toko mencerminkan kemantapan dan kekokohan spirit perusahaan dan sifat kegiatan yang ada didalamnya, serta dapat menciptakan kepercayaan dan goodwill bagi konsumen. Store exterior berfungsi sebagai identifikasi atau tanda pengenalan, sehingga sering menyatakan lambang. Dengan karakteristik store exterior, yaitu:

1) Tampilan depan toko.

2) Nama atau logo toko.

3) Pintu masuk toko.

b) General interior, dari suatu toko harus dirancang untuk memperoleh kesan yang menyenangkan. Kesan ini diciptakan oleh warna dinding toko yang menarik, musik yang diperdengarkan aroma 
dan display produk. Tapi paling utama yang dapat membuat penjualan setelah pembelian berada di store adalah display. Display yang baik adalah yang dapat menarik minat konsumen dan membantu mereka agar mudah mengamati, memeriksa dan memilih barang-barang dan akhirnya melakukan pembelian. Dengan karakteristik general interior, yaitu:

1) Pencahayaan.

2) Peralatan penunjang.

3) Suhu.

4) Display menarik.

5) Tampilan produk.

6) Kasir.

7) Kebersihan.

c) Store layout atau tata letak toko, merupakan rencana untuk untuk menentukan lokasi tertentu dan pengaturan dari jalan/gang di dalam toko yang cukup lebar untuk memudahkan para konsumen untuk berlalu lalang didalam toko. Layout yang baik akan mengundang konsumen untuk betah berkeliling lama-lama dan membelanjakan uangnya lebih banyak. Dilihat dari indikatornya seperti lokasi ruangan dan pengelompokan produk.

d) Interior display atau papan pengumuman merupakan tanda yang digunakan untuk memberikan informasi kepada konsumen untuk mempengaruhi suasana lingkungan toko. Dilihat dari indikatornya seperti theme setting display dan poster.

\section{Brand Ambassador}

\section{Pengertian Brand Ambassador}

Brand ambassador menurut Shimp (2014:259) adalah pendukung iklan atau juga yang dikenal sebagai bintang iklan yang mendukung produk yang diiklankan. Sedangkan menurut kotler dan Amstrong (2014:163) mengatakan bahwa brand ambassador merupakan individu yang menyebarkan informasi mengenai produk dari suatu perusahaan. Sedangkan menurut Kertamukti (2015:71) brand ambassador adalah individu yang terkenal oleh publik atas prestasinya selain dari pada produk yang didukungnya penggunaan brand ambassador dimaksudkan untuk mempromosikan suatu produk dan mempermudah tumbuhnya keyakinan konsumen atas produk yang diiklankannya.

Dari beberapa teori yang sudah dikemukakan maka dapat diambil kesimpulan bahwa brand ambassador adalah seseorang individu terkenal yang dijadikan pendukung iklan untuk menyebarluaskan informasi mengenai suatu produk dari perusahaan agar mempermudah tumbuhnya keyakinan dalam benak konsumen akan produk yang diiklankannya.

\section{Fungsi Brand Ambassador}

Menurut Kertamukti (2015:69) Selebriti yang digunakan untuk mempromosikan suatu produk, bisa berfungsi untuk:

a) Memberi kesaksian (testimonial)

b) Memberikan dorongan dan penguatan

c) Bertindak sebagai aktor dalam iklan

d) Bertindak sebagai juru bicara perusahaan

\section{Alasan Utama Menggunakan Brand Ambassador}

Penggunaan brand ambassador didalam mendukung iklan memiliki empat alasan utama menurut Kertamukti (2015:71), yaitu:

a) Pemasar rela membayar tinggi selebritis yang banyak disukai oleh masyarakat. Selebritis digunakan untuk menarik perhatian khalayak dan meningkatkan awarness produk.

b) Pemasar mengharapkan persepsi konsumen terhadap produk tersebut akan berubah.

c) Akan menimbulkan kesan bahwa konsumen selektif dalam memilih.

d) Meningkatkan status dengan memiliki apa yang digunakan selebriti. 


\section{Jenis-Jenis Brand Ambassador}

Pemilihan jenis brand ambassador/endorse didasarkan pada jenis produk dan tujuan periklanannya. Jenis-jenis brand ambassador/endoser dalam iklan menurut Kertamukti (2015:72), yaitu:

a) Expert

Penggunaan tokoh yang memiliki keahlian pada bidang tertentu yang relevan dengan produk yang diiklankannya. Penggunaan tokoh ahli ini dimaksudkan agar konsumen yakin akan keunggulan teknis produk tersebut. Contoh: penggunaan teknisi atau montir dalam iklan pelumas atau iklan mesin dan dokter dalam produk obat-obatan.

b) Prominence

Penggunaan tokoh yang dikenal dan dipercaya oleh masyarakat. Penggunaan tokoh terkenal ini agar konsumen menganggap produk tersebut sebagai produk yang terkenal seperti tokoh (endoser), produk yang baik/berkualitas karena dipakai oleh tokoh terkenal. Contoh: penggunaan tokoh pengacara rudi lontoh dalam iklan BMW 5301.

c) Celebrity

Pengunaan artis, penyanyi, bintang film yang disukai masyarakat luas untuk mengiklankan produk tertentu. Pengunaan artis ini agar konsumen juga menyukai produk tersebut seperti mereka menyukai artis atau bintang yang mengiklankannya. Contoh: penggunaan Agnes Monica dalam Ale-Ale dan Shampo Head and Shoulder.

d) Testimonial

Penggunaan tokoh yang berasal dari kalangan orang biasa yang dianggap netral (tidak memihak) untuk menyampaikan pernyataan (testimonial) tentang keunggulan produk. fungsinya: penggunaan orang biasa ini agar melalui pernyataan orang tersebut, konsumen dapat diyakinkan akan kejujuran produsen atas keunggulan produk tersebut. contoh: orang bali dalam iklan isuzu panther, ibu rumah tangga dalam iklan rinso.

e) Teresterial

Penggunaan orang biasa dan tidak komersial sesuai dengan lingkungan dimana produk tersebut dipasarkan/dibuat. Penggunaan tokoh ini agar konsumen yakin bahwa keunggulan produk tersebut membang benar, dengan melihat kesaksian dari masyarakat di sekitar pabrik/daerah pemasaran produk tersebut. contoh: iklan kampanye lngkungan hidup dari PT Freepot yang menggunakan orang irian jaya.

f) Clientel

Penggunaan tokoh yang telah menjadi pelanggan/konsumen dari produk yang diiklankan.pengguna tokoh ahli ini agar melalui pengakuan dari konsumen yang telah membeli/menggunakan produk tersebut, para calon konsumen yakin akan keunggulan produk yang diiklankan. Contoh: penggunaan nasabah dalam iklan bank/asuramsi

g) Leader

Penggunaan tokoh yang merupakan pimpinan pada bidang tertentu yang relevan dengan produk yang diiklankan. Penggunaan tokoh ahli ini agar konsumen yakin akan keunggulan produk tersebut. contoh: penggunaan tokoh masyarakat dalam iklan keluarga berencana

h) Accesivist

Penggunaan tokoh yang memiliki keunikan pada bidang tertentu. Penggunaan tokoh ahli ini agar konsumen tertarik atas penampilan tokoh unik tersebut dan kemudian juga akan memperhatikan iklan yang ditayangkan. Contoh: penggunaan orang dengan bentuk badan yang unik (sangat tinggi/sangat pendek)

i) Superority

Penggunaan tokoh yang memiliki keunggulan/prestasi pada bidang tertentu. Contoh: penggunaan atlet juara dalam iklan obat flu atau produk sosis.

\section{Kekurangan menggunakan Brand Ambassador dalam iklan}

Kekurangan dalam penggunaan brand ambassador/endorse dalam iklan menurut Kertamukti (2015:74), yaitu:

a) Produknya berkaitan dengan brand personality (watak merek), jangan menggunakan model iklan yang sudah dipakai oleh banyak iklan, mengakibatkan konsumen menjadi bosan. 
b) Endosernya berkaitan dengan bagaimana personality (kepribadian) dari masing-masing endoser. Model iklan paling diingat terlihat dari tarif seseorang model semakin besar karena semakin terkenal, semakin sering dipakai sebagai model. Tapi produknya belum tentu terkenal oleh masyarkat.

\section{Karakteristik Brand Ambassador}

Menurut Shimp (2014:260) karakteristik yang diperlukan oleh brand ambassador adalah:

a) Trustworthy / Kepercayaan

Trustworhty atau kepercayaan mengacu pada kejujuran, integritas, dan dipercayainya seseorang pendukung. Para pemasang iklan memanfaatkan nilai kepercayaan dengan memilih brand ambassador yang secara luas dipandang jujur, dapat dipercaya dan dapat diandalkan. Trustworhty juga menyangkut seberapa besar kepercayaan masyarakat terhadap endorser yang dapat mempengaruhi keputusan pembelian konsumen.

b) Expertise / Keahlian

Pengetahuan public figur tentang produk yang diiklankan mengacu pada pengetahuan, pengalaman atau keterampilan yang dimiliki oleh seseorang ambassador yang dihubungkan dengan topik iklannya.

c) Physical Attractiviness / Daya tarik

Daya tarik meliputi keramahan, menyenangkan, fisik dan pekerjaan sebagai beberapa dimensi penting dari konsep daya tarik. Menggunakan brand ambassador tidak hanya selebriti yang sedang populer saja tetapi image yang positif di masyarakat.

d) Personal Image / Citra diri

Personal image adalah kesan yang didapatkan pada diri seseorang brand ambassador, baik atau buruk citra seseorang selebtiri akan terus melekat pada benak konsumen dan mempengaruhi persepsi konsumen pada produk yang diiklankan.

\section{Dimensi dan Indikator Brand Ambassador}

Dimensi brand ambassador menurut Rossiter dan Percy dalam Kertamukti (2015:70) diketahui sebagai berikut:

A. Visibility (kepopuleran), popularitas yang melekat pada brand ambassador yang mewakili produk tersebut. dapat dilihat bahwa visibility (kepopuleran) memiliki indikatornya seperti dikenal luas oleh masyarakat, memiliki peran yang luas di masyarakat, pesona yang memikat masyarkat.

B. Credibility (kredibilitas), kredibilitas adalah seperangkat persepsi komunikan tentang sifat sifat komunikator. Credibility (kredibilitas) dapat dilihat dari indikator seperti brand ambassador dipandang jujur dalam membawakan sebuah iklan dan karakter keahlian yang menunjukan seberapa luas pengetahuan public figur

C. Attraction (daya tarik), daya tarik brand ambassador terdiri dari dua karakterstik, kepesonaan dan kepribadian. Attraction (daya tarik) memiliki indikator seperti karakter kepribadian brand ambassador.

D. Power (kekuatan), kekuatan selebriti tersebut untuk membujuk para konsumen dalam produk yang diiklankan. Hal ini dapat dilihat dari indikatiornya bahwa public figur memiliki fisik menarik yang menjadi pujaan oleh masyarakat.

\section{Green Marketing}

\section{Pengertian Green Marketing}

Green marketing menurut Chen dan Chang (2013) adalah konsep yang meliputi semua kegiatan pemasaran yang dikembangkan untuk merangsang dan mempertahankan sikap perilaku yang ramah lingkungan. Sedangkan menurut pride dan Farrel dalam Donni Juni Priansa (2017) Green marketing merupakan usaha organisasi atau perusahaan dalam mendesain promosi, harga dan distribusi produk-produk yang tidak merugikan lingkungan. Sedangkan menurut Allen Manongko (2018:32). Green marketing pertimbangan lingkungan yang diintegrasikan ke dalam semua aspek pemasaran, pengembangan produk, proses produksi, pengemasan serta modifikasi 
iklan, dengan pendekatan marketing mix (produk, price, place, promotion) dan theory of planned behaviour terhadap environmental concern dan green marketing consumerism.

Dari beberapa teori yang sudah dikemukakan maka dapat diambil kesimpulan bahwa green marketing adalah pemasaran unik yang diintegrasikan kedalam aspek pemasaran seperti promosi, harga dan distribusi produk-produk dengan selalu mengutamakan sikap ramah lingkungan.

\section{Konsep Green Marketing}

Menurut Allen Manongko (2018:24) green marketing adalah sebuah konsep strategi pemasaran produk oleh produsen yang peduli lingkungan hidup bagi kebutuhan konsumen yang peduli lingkungan hidup. Pada dasarnya kedua belah pihak diuntungkan dengan nilai tambah bahwa orang-orang disekitar mendapatkan keuntungan atas keadaan lingkungan yang membaik karena green marketing mengedepankan green input - green process - maupun green output.

\section{Manfaat Green Marketing}

Konsep green marketing merupakan alternatif yang dapat digunakan pemasar dalam melaksanakan aktivitas pemasaran dengan memanfaatkan sumber daya yang terbatas secara efisien dan efektif, menurut Donni Juni Priansa (2015:284) melalui konsep green marketing akan diperoleh manfaat secara langsung, yaitu:

a) Menghasilkan produk yang ramah lingkungan.

b) Para produsen dan pemasang iklan mengembangkan produk yang mereka upayakan untuk memenuhi keinginan masyarakat yang peduli lingkungan.

c) Inovasi. Kecintaan terhadap lingkungan akan membuat perusahaan menjadi lebih inovatif, baik inivatif dalam input, process, output maupun strategi marketing.

\section{Tujuan Green Marketing}

Tujuan green marketing tidak hanya melihat profit sebagai satu-satunya tujuan perusahaan, tetapi ada tambahan kepudilian lingkungan terhadap lingkungan hidup. Jhon Grant dalam Donni Juni Priansa (2017:283) membagi tujuan green marketing ke dalam tiga tahap berikut.

a) Green

Bertujuan kearah komunikasi bahwa merek atau perusahaan adalah peduli lingkungan hidup. Tahapan ini merupakan tahapan awal bagi perusahaan yang menerapkan konsep green marketing.

\section{b) Greener}

Selain komersialisasi sebagai tujuan utama perusahaan, adapula tujuan yang berpengaruh kepada lingkungan hidup. Perusahaan mencoba mengubah gaya konsumen mengkonsumsi atau memakai produk. misalnya, penghematan kertas dapat dengan menggunakan kertas bekas ataupun kertas recycle. Penghematan air, listrk, penggunaan AC dan lain-lain.

c) Greenest

Perusahaan berusaha mengubah budaya konsumen ke arah yang lebih peduli lingkungan hidup. Budaya konsumen yang diharapkan adalah kepedulian terhadap lingkungan dalam semua aktivitas, tanpa terpengaruh oleh produk perusahaan yang ditawarkan.

\section{Hambatan dan Solusi Green Marketing}

Satish C. Sharma dalam Donni Juni Priansa (2017:294) menyatakan banyak keprihatinan mengenai kelangsungan hidup komersil produk hijau mencul karena adanya hambatan berikut.

a) Kurangnya kesadaran

Konsumen sama-sama bingung untuk membeli produk ramah lingkungan dengan alasan yang baik. Oleh karena itu perusahaan harus menciptakan kesadaran dikalangan konsumen mengenai produk hijau dan memfasilitasi penjualan mereka.

b) Persepsi negatif

Ketika konsumen dapat mengidentifikasi produk-produk ramah lingkungan, label hijau kadangkadang terbukti menjadi berbahaya.

c) Ketidakpercayaan

Sebuha studi 2007 okehterra Choice Environmental Marketing Inc. (The six sins of gren Washing) meneliti 1.753 klaim produk lingkungan dan menemukan bahwa semua, kecuali satu, 
adalah menyesatkan atau hanya palsu. Dalam kategori menyesatkan, beberapa perusahaan produk fitur yang sebenarnya dimanfaatkan oleh hukum.

d) Harga yang tinggi

Harga dianggap sebagai penghalang terbesar untuk membeli produk hijau. Dalam sebuah survei terhadap 3.600 konsumen green product di inggris diketahui bahwa pasar tidak cukup dewasa untuk menerima produk-produk hijau karena harganya lebih tinggi dibanding dengan produk non-hijau.

\section{Strategi Green Marketing}

Upaya untuk mengatasi hambatan dalam green marketing tersebut dilakukan dengan strategi green marketing. Strategi green marketing sesungguhnya bukan sebuah startegi baru, namun karakter yang berhubungan dengan konsep green, berikut strategi green marketing yang dikemukakan Nandini dalam buku Allen Manongko (2018:37):

a) Segmentasi pasar yang terkonsentrasi pada segmentasi pasar terpilih.

b) Mengembangkan generasi baru dari green product yang artinya perusahaan harus mempertimbangkan efek negatif sebuah produk terhadap lingkungan dan berusaha meminimalisasikannya sejak dari tahap awal pengembangan produk.

c) Green positioning, perusahaan yang tertarik untuk memposisikan perusahaannya sebagai perusahaan yang green harus memastikan semua kegiatannya sesuai dengan citra yang dikomunikasikan dan tidak melakukan kebohongan termasuk kebohongan melalui media.

d) Applying green promotion, kegiatan promosi perusahaan akan kepedulian terhadap lingkungan akan sia-sia jika aktivitasnya tidak sesuai dengan apa yang dipromosikan.

e) Green packaging, perusahaan yang memproduksi dan menggunakan kemasan pada produknya dapat mengganti kemasan produk dengan kemasan ramah lingkungan (eco-friendly). Kemasan tersebut dapat digunakan sebagai alat bantu untuk konsumen yang peduli terhadap lingkungan dalam memilih produk.

f) Appliying green logistics, mendesain kemasan yang efisien selain dapat memudahkan proses distribusi produk juga dapat mengurangi sampah dalam jumlah besar.

g) Changing the attitude towards waste, menggunakan kemasan yang dapat didaur ulang dapat menciptakan pasar baru karena limbah produksi yang dapat didaur ulang dapat menjadi bahan baku untuk perusahaan lain.

Selain strategi diatas, Nandini menambahkan beberapa strategi green marketing yang menjadi pertimbangan:

a) Being genue, perusahaan yang sungguh-sungguh melakukan bisnis yang mengkampanyekan green marketing, seluruh kebijakan bisnis yang dirumusukannnya pun secara konsisten mendukung segala aktivitas perusahaan yang mencerminkan kegiatan ramah lingkungan.

b) Educate your customer, perusahaan tidak hanya mengkomunikasikan bahwa perusahaan tersebut melakukan kegiatan peduli terhadap lingkungan tetapi juga menjelaskan mengapa hal tersebut penting dilakukan.

c) Give your customer an opportunity to participate, menciptakan manfaat personal dengan melibatkan konsumen dalam kegiatan pelestarian lingkungan.

d) Know your customer, hal pertama yang harus dilakukan oleh perusahaan sebelum menjual produknya adalah memastikan bahwa konsumen yang dituju adalah konsumen yang menyadari dan peduli terhadap isu yang ingin diatasi oleh perusahaan.

e) Empower consumers, Memastikan bahwa konsumen merasakan sendiri, maupun bersama-sama dengan konsumen lainnya dapat menciptakan perubahan. Pemberdayaan konsumen tersebut dapat merupakan alasan utama mengapa konsumen bersedia membeli green product.

f) Be transparent, konsumen harus memiliki kepercayaan terhadap legitimasi perusahaan dalam mengkomunikasikan produk yang dihasilkan. Maka dari itu, perusahaan harus mengungkapkan informasi penting terkait untuk menciptakan ekonomi ramah lingkungan.

\section{Dimensi dan Indikator Green Marketing}

Menurut Allen Manongko (2018:86) dimensi dari green marketing terdiri dari konsep marketing mix yaitu product, price, place dan promotion: 
a) Green product, adalah setiap produk yang tidak berbahaya bagi lingkungan dan kosnumen dan juga bekerja sebagai obat masa depan dari dampak negatif suatu produk. Dengan indikator sebagai berikut :

1) Produk tahan lama.

2) Bahan baku yang digunakan alami.

3) Menyediakan produk re-cycle

b) Harga premium, merupakan pertimbangan penting dari konsumen untuk membeli produk hijau. Perbedaan harga yang signifikan didasari konsekuensi dari produk. harga premium dapat dilihat dari indikatornya seperti bahan baku pada produk itu sendiri dan kemasan/label.

c) Green place, sebagai proses penyediaan, penyaluran barang atau jasa dari produsen ke konsumen. Green place dapat dilihat dari indikatornya seperti lokasi dan ketersediaan produk.

d) Green Promotion, adalah suatu strategi dari konsep green marketing untuk memasarkan produk ramah lingkungan. Dengan indikator sebagai berikut:

1) Promosi dengan memperhatikan lingkungan.

2) Promosi mengangkat isu lingkungan.

3) Promosi dilakukan dengan menarik.

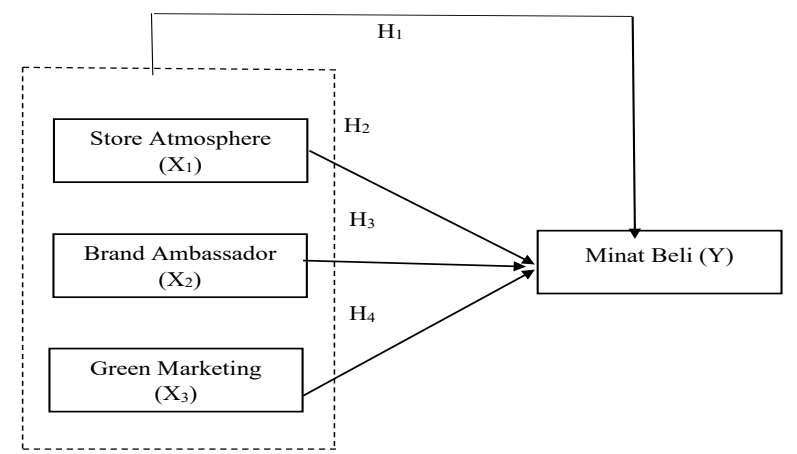

\section{METODOLOGI PENELITIAN}

Penelitian ini merupakana penelitian kausal, penelitian ini dilakukan di Store Innisfree Central Park Mall, lantai LG Jl.Letjen S Parman No.28 Jakarta. Penelitian ini ditujukan untuk konsumen yang berminat membeli produk innisfree. Didapat 100 orang responden dengan pengumpulan data menggunakan kuisioner yang dianalisis menggunakan regresi linier berganda.

\section{HASIL DAN PEMBAHASAN}

\section{Tabel 1 Uji Regresi Linier berganda}

\begin{tabular}{|c|c|c|c|c|c|}
\hline \multicolumn{6}{|c|}{ Coefficients $^{a}$} \\
\hline \multirow[b]{2}{*}{ Model } & \multicolumn{2}{|c|}{$\begin{array}{l}\text { Unstandardized } \\
\text { Coefficients }\end{array}$} & \multirow{2}{*}{$\begin{array}{c}\begin{array}{c}\text { Standardized } \\
\text { Coefficients }\end{array} \\
\text { Beta } \\
\end{array}$} & \multirow[b]{2}{*}{$\mathrm{T}$} & \multirow[b]{2}{*}{ Sig. } \\
\hline & $\mathrm{B}$ & $\begin{array}{l}\text { Std. } \\
\text { Error }\end{array}$ & & & \\
\hline $\begin{array}{ll}1 & \text { (Constant) }\end{array}$ & 19,640 & 6,501 & & 3,021 &, 003 \\
\hline STORE ATMOSPHERE &, 124 &, 110 &, 117 & 1,123 & ,264 \\
\hline BRAND AMBASSADOR & 042 & ,112 &, 028 & 377 & ,707 \\
\hline GREEN MARKETING & 909 & ,134 & 667 & 6,763 &, 000 \\
\hline
\end{tabular}

a. Dependent Variable: MINAT BELI

Sumber: Data diolah peneliti 2020

Persamaan regresi dari output SPSS diatas adalah sebagai berikut:

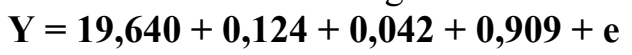

Berdasarkan persamaan regresi diatas maka dapat disimpulkan: 
1) Nilai konstanta sebesar 19,640 yang berarti jika variabel store atmosphere $\left(\mathrm{X}_{1}\right)$, brand ambassador $\left(\mathrm{X}_{2}\right)$ dan green marketing $\left(\mathrm{X}_{3}\right)$ bernilai 0 maka minat beli konsumen $(\mathrm{Y})$ bernilai 19,640

(a) Nilai koefisien regresi variabel store atmosphere $\left(\mathrm{X}_{1}\right)$ sebesar 0,124 bernilai positif mempunyai arti bahwa jika represi terhadap store atmosphere $\left(\mathrm{X}_{1}\right)$ semakin baik, maka minat beli konsumen meningkat.

(b) Nilai koefisien regresi variabel brand ambassador $\left(\mathrm{X}_{2}\right)$ sebesar 0,042 bernilai positif mempunyai arti bahwa jika represi terhadap brand ambassador $\left(\mathrm{X}_{2}\right)$ semakin baik, maka minat beli konsumen meningkat.

(c) Nilai koefisien regresi variabel green marketing $\left(\mathrm{X}_{3}\right)$ sebesar 0,909 bernilai positif mempunyai arti bahwa jika represi terhadap green marketing $\left(\mathrm{X}_{3}\right)$ semakin baik, maka minat beli konsumen meningkat.

\section{Tabel 2 Hasil Uji F Simultan}

\begin{tabular}{|c|c|c|c|c|c|c|}
\hline \multicolumn{7}{|c|}{ ANOVA $^{\mathrm{a}}$} \\
\hline \multicolumn{2}{|c|}{ Model } & $\begin{array}{c}\text { Sum of } \\
\text { Squares }\end{array}$ & Df & $\begin{array}{l}\text { Mean } \\
\text { Square }\end{array}$ & $\mathrm{F}$ & Sig. \\
\hline \multirow[t]{3}{*}{1} & Regression & 8162,833 & 3 & 2720,944 & $\begin{array}{r}47,06 \\
2\end{array}$ &, $000^{\mathrm{b}}$ \\
\hline & Residual & 5550,327 & 96 & 57,816 & & \\
\hline & Total & 13713,160 & 99 & & & \\
\hline \multicolumn{7}{|c|}{ a. Dependent Variable: MINAT BELI } \\
\hline
\end{tabular}

Menentukan $\mathrm{F}_{\text {hitung }}$ dengan cara melihat $\mathrm{F}_{\text {tabel }}$ dengan $\operatorname{df}(\mathrm{n} 1)=\mathrm{k}-1$ atau $\operatorname{df}(\mathrm{n} 2)=\mathrm{n}-\mathrm{k}$ atau df $1=4-1=3$ dan df $2=100-4=96$ sehingga diperoleh $\mathrm{f}_{\text {tabel }}$ sebesar 2,70 .

Berdasarkan tabel diatas dapat diketahui nilai $F_{\text {hitung }}$ sebesar 47,062 dan $F_{\text {tabel }} 2,70$ dengan nilai signifikan yang diperoleh 0,000 berarti lebih kecil dari tingkat signifikansi 0,05 . Oleh karena itu nilai $\mathrm{f}_{\text {hitung }}>\mathrm{f}_{\text {tabel }}$ dan nilai sig $<0,05$ maka Ho ditolak dan Ha diterima. Sehingga dapat disimpulkan bahwa store atmosphere $\left(\mathrm{X}_{1}\right)$, brand ambassador $\left(\mathrm{X}_{2}\right)$ dan green marketing $\left(\mathrm{X}_{3}\right)$ secara simultan berpengaruh terhadap minat beli konsumen $(\mathrm{Y})$

\section{Tabel 3 Hasil Uji t Parsial}

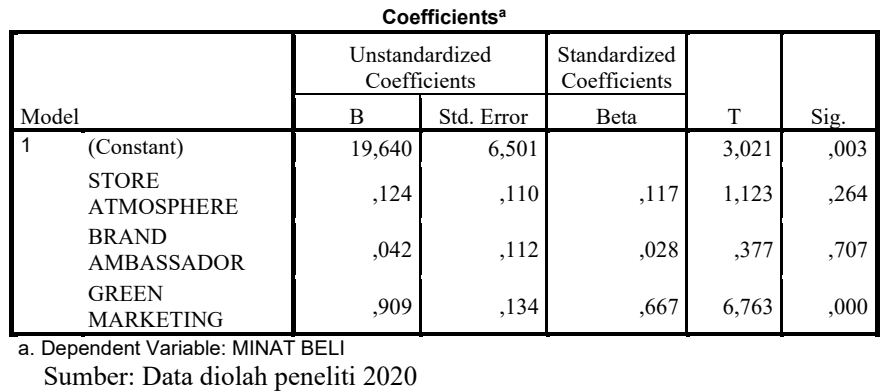

Menentukan $\mathrm{t}_{\text {hitung }}$ dapat dilihat pada $\mathrm{t}_{\text {tabel }}$ signifikan 0,05 dengan derajat kebebasan $\mathrm{df}=\mathrm{n}-\mathrm{k}-$ 1 , atau $\mathrm{df}=100-4-1=95$ maka diperoleh $\mathrm{t}_{\text {tabel }}$ sebesar 1,984. berikut:

Berdasarkan perhitungan pada tabel dapat diuraikan hasil pengujian hipotesis parsial sebagai

(a) Variabel store atmosphere mempunyai nilai $t_{\text {hitung }} 1,123<t_{\text {tabel }}$ 1,984 dengan nilai signifikansi $0,264>0,05$ sehingga Ho diterima Ha ditolak, berarti tidak terdapat pengaruh signifikan variabel store atmosphere terhadap minat beli konsumen. 
(b) Variabel brand ambassador mempunyai nilai thitung $0,377<t_{\text {tabel }} 1,984$ dengan nilai signifikansi $0,707>0,05$ sehingga Ho diterima Ha ditolak, berarti tidak terdapat pengaruh signifikan variabel brand ambassador terhadap minat beli konsumen.

(c) Variabel green marketing mempunyainilai $t_{\text {hitung }} 6,763>t_{\text {tabel }}$ 1,984 dengan nilai signifikansi $0,000<0,05$ sehingga Ho ditolak Ha diterima, berarti terdapat pengaruh signifikan variabel green marketing terhadap minat beli konsumen

Tabel 4 Analisis Koefisien Determinasi $\left(\mathbf{R}^{2}\right)$

\begin{tabular}{|c|c|c|c|c|}
\hline \multicolumn{5}{|c|}{ Model Summary ${ }^{b}$} \\
\hline Model & $\mathrm{R}$ & R Square & $\begin{array}{l}\text { Adjusted R } \\
\text { Square }\end{array}$ & $\begin{array}{l}\text { Std. Error of the } \\
\text { Estimate }\end{array}$ \\
\hline 1 &, $772^{a}$ &, 595 &, 583 & 7,604 \\
\hline
\end{tabular}

Dalam penelitian ini store atmosphere $\left(\mathrm{X}_{1}\right)$, brand ambassador $\left(\mathrm{X}_{2}\right)$ dan green marketing $\left(\mathrm{X}_{3}\right)$ berpengaruh sebesar 58,3\% terhadap minat beli konsumen $(\mathrm{Y})$ dan sisanya sebesar $(100 \%$ $58,3 \%=41,7 \%$ ) dipengaruhi oleh variabel lain yang tidak dijelaskan dalam penelitian ini.

\section{PEMBAHASAN DAN HASIL INTERPRESTASI HASIL PENELITIAN}

\section{Pengaruh Store Atmosphere Terhadap Minat Beli Konsumen}

Berdasarkan hasil uji hipotesis menunjukan bahwa variabel Store Atmosphere $\left(\mathrm{X}_{1}\right)$ tidak berpengaruh secara signifikan terhadap minat beli konsumen Innisfree, hal itu diketahui dari nilai $\mathrm{t}_{\text {hitung }} 1,123<\mathrm{t}_{\text {tabel }} 1,984$ dan nilai signifikansi sebesar 0,264 $>0,05$ sehingga Ho diterima Ha ditolak.

Menurut Kotler dan Keller yang dialih bahasakan oleh Bob Sabran (2013:69) bahwa minat perilaku muncul akibat dari afektif (perasaan) yang dimiliki oleh konsumen. Perasaan emosional seseorang dapat muncul dalam suasana tak terencana misalnya melihat keindahan atmosphere seperti toko yang menarik dan berbeda. Sebuah toko yang memiliki kepribadian yang baik dalam atmosphere akan memiliki tingkat kemungkinan dipilih oleh konsumen lebih tinggi dibandingkan dengan yang tidak baik. Hasil penelitian ini tidak sejalan dengan pendapat yang dikemukakan oleh Kotler dan Keller yang dialih bahasakan oleh Bob Sabran (2013). Namun hasil penelitian ini memiliki kesamaan hasil dengan penelitian dari Rinrin Karina Rakhmawati (2018) yang menyatakan bahwa Store Atmosphere tidak berpengaruh signifikan terhadap minat beli pada transmart carrefour buah batu Bandung.

Dari tabulasi data pada variabel Store Atmosphere yang terdiri dari 4 dimensi yaitu store exterior, general exterior, store layout dan interior display. Menunjukkan bahwa responden menganggap store atmosphere di Innisfree sudah baik. Hal ini dilihat dari nilai skor rata-rata pada variabel store atmosphere sebesar 4,38. Namun jika dilihat per-dimensi pada variabel store atmosphere skor terendah adalah interior display dengan nilai 4,31 yang berarti papan pengumuman berupa poster sudah informatif dan menarik konsumen namun tidak memberikan dampak pada minat beli bahkan pada keputusan pembelian. Sedangkan untuk dimensi general interior memiliki skor 4,41 dimana pada dimensi ini responden Innisfree melihat bahwa dalam hal pengaturan general interior yang meliputi pencahyaan, peralatan penunjang, suhu, display menarik, tampilan produk juga dianggap baik serta kebersihan, namun hal itu belum mampu menarik minat beli konsumen.

\section{Pengaruh Brand Ambassador Terhadap Minat Beli Konsumen}

Berdasarkan hasil uji hipotesis menunjukkan bahwa variabel Brand Ambassador $\left(\mathrm{X}_{2}\right)$ tidak berpengaruh secara signifikan terhadap minat beli konsumen Innisfree, hal itu diketahui dari nilai 
$\mathrm{t}_{\text {hitung }} 0,377<\mathrm{t}_{\text {tabel }} 1,984$ dan nilai signifikansi sebesar $0,707>0,05$ sehingga Ho diterima Ha ditolak.

Menurut Kertamukti (2015:71) bahwa minat konsumen didasari oleh promosi menarik yang dilakukan dengan memilih individual yang terkenal oleh publik atau biasa kita sebut dengan public figur untuk menumbuhkan keyakinan suatu produk. kecenderungan masyarakat mengikuti gaya hidup public figur memiliki pengaruh yang baik terhadap minat beli. Hasil penelitian ini tidak sejalan dengan pendapat yang dikemukakan oleh Kertamukti (2017). Namun hasil penelitian ini memiliki kesamaan hasil dengan penelitian Sandi Fatahillah (2019) yang menyatakan bahwa Brand Ambassador tidak berpengaruh signifikan terhadap minat beli konsumen produk eiger adventure di kota Makassar.

Dari tabulasi data pada variabel Brand Ambassador yang terdiri dari 4 dimensi yaitu visibility, credibility, attarction, dan power. Menunjukkan bahwa responden menganggap brand ambassador Innisfree sudah baik. Hal ini dilihat dari skor nilai rata-rata pada variabel brand ambassador sebesar 4,25. Namun jika dilihat per-dimensi pada variabel brand ambassador skor terendah adalah credibility dengan nilai 4,08 yang berarti kredibilitas baik yang dimiliki brand ambassador Innisfree tidak memberikan dampak pada minat beli bahkan pada keputusan pembelian. Sedangkan untuk dimensi visibility memiliki skor 4,37 dimana pada dimensi ini responden Innisfree setuju kepopuleran yang dimiliki brand ambassador Innisfree sudah baik namun hal itu belum mampu menarik minat beli konsumen.

\section{Pengaruh Green Marketing Terhadap Minat Beli Konsumen}

Berdasarkan hasil uji hipotesis menunjukkan variabel Green Marketing $\left(\mathrm{X}_{3}\right)$ berpengaruh secara signifikan terhadap minat beli konsumen Innisfree, hal itu diketahui dari nilai $t_{\text {hitung }} 6,763>$ $\mathrm{t}_{\text {tabel }} 1,984$ dengan nilai signifikansi sebesar $0,000<0,05$ sehingga Ho ditolak Ha diterima.

Menurut Donni Juni Priansa (2017) bahwa minat perilaku muncul karena adanya konsep Green marketing. Green marketing mendesain promosi, harga dan distribusi produk-produk yang tidak merugikan lingkungan. Sebuah perusahaan yang mimiliki kepedulian terhadap lingkungan akan memiliki tingkat kemungkinan dipilih oleh konsumen. Hasil penelitian ini sejalan dengan pendapat Donni Juni Priansa (2017) dan memiliki kesamaan hasil dengan penelitian Murwanto Sigit (2016) yang menyatakan bahwa Green Marketing berpengaruh secara signifikan terhadap minat beli pada pelanggan NavaGreen natural skincare Yogyakarta.

Dari tabulasi data pada variabel Green marketing yang terdiri dari 4 dimensi yaitu green product, harga premium, green place dan green promotion. Menunjukkan bahwa responden menganggap konsep green marketing di Innisfree sudah baik. Hal ini dilihat dari nilai skor rata-rata pada variabel green marketing sebesar 4,22. Jika dilihat per-dimensi pada variabel green marketing skor terendah adalah harga premium dengan nilai 4,15 yang berarti harga produk ramah lingkungan cukup mahal namun memberikan dampak pada minat beli bahkan pada keputusan pembelian. Sedangkan untuk dimensi green product memiliki skor 4,28 dimana pada dimensi ini responden Innisfree sepakat bahwa green product yang meliputi produk tahan lama, bahan baku alami dan produk re-cycle mampu menarik minat beli konsumen.

\section{KESIMPULAN DAN SARAN}

\section{A. Kesimpulan}

Dari hasil analisis yang dilakukan mengenai Store Atmosphere, Brand Ambassador dan Green Marketing terhadap Minat Beli Konsumen, terdapat kesimpulan yang dapat ditarik dari penelitian ini, sebagai berikut:

1. Secara simultan Terdapat pengaruh yang signifikan antara Store Atmosphere, Brand Ambassador dan Green Marketing pada store Innisfree Central Park Mall terhadap Minat Beli Konsumen sebesar $58,3 \%$ dan sisanya $41,7 \%$ dipengaruhi oleh variabel lain yang tidak dijelaskan dalam penelitian ini.

2. Tidak terdapat pengaruh yang signifikan antara Store Atmosphere pada store Innisfree Central Park Mall terhadap Minat Beli Konsumen.

3. Tidak terdapat pengaruh yang signifikan antara Brand Ambassador pada store Innisfree Central Park Mall terhadap Minat Beli Konsumen. 
4. Terdapat pengaruh yang signifikan antara Green Marketing pada store Innisfree Central Park Mall terhadap Minat Beli Konsumen.

\section{B. Saran}

Adapun saran untuk store Innisfree Central Park Mall antara lain:

1. Berdasarkan hasil kuesioner dan pembahasan mengenai variabel store atmosphere, store atmosphere yang berada pada Innisfree Central Park Mall berada dalam kategori cukup menurut tanggapan responden, namun hasil uji t memberikan hasil bahwa store atmosphere secara parsial tidak berpengaruh signifikan terhadap minat beli maka dari itu Innisfree Central Park Mall perlu memperbaharui strategi yang dapat menarik minat beli serta meningkatkan penjualan produk Innisfree.

2. Berdasarkan hasil kuesioner dan pembahasan mengenai variabel brand ambassador, brand ambassador yang dimiliki Innisfree berada dalam kategori cukup menurut tanggapan responden. Namun hasil dari uji t bahwa brand ambassador secara parsial tidak berpengaruh signifikan terhadap minat beli konsumen, maka hal ini perlu dilakukan evaluasi terkait promosi yang dilakukan Innisfree dengan mengganti promosi menggunakan brand ambassador karena mengingat bahwa konsumen tertarik pada innisfree melalui brand ambassador tetapi tidak dapat meningkatkan penjualan maka dari itu innisfree harus menggantikan promosi karena dirasa kurang efektif dalam meningkatkan penjualan.

3. Berdasarkan hasil kuesioner dan pembahasan mengenai variabel green marketing, konsep green marketing pada Innisfree sudah berada dalam kategori baik menurut tanggapan responden. Seluruh kegiatan produksi sampai produk berada ditangan konsumen, Innisfree selalu mementingkan keselamatan lingkungan hal ini menjadi daya tarik Innisfree dalam meningkatkan minat beli yang berkolerasi pada keputusan pembelian. Mengingat hasil uji $\mathrm{t}$ bahwa green marketing secara parsial berpengaruh secara signifikan terhadap minat beli maka dari itu manajemen Innisfree perlu mempertahankan dan mengembangkan konsep green marketing untuk memberikan dampak positif pada minat beli.

\section{DAFTAR PUSTAKA}

\section{Sumber Buku:}

Barry Berman dan Joel R. Evans, 2014. Retail Management dialih bahasakan oleh Lina Salim, 12 th. Edition, Jakarta: Pearson.

Kertamukti, Rama. 2015. Strategi Kreatif Dalam Periklanan, Jakarta: Raja Grafindo Persada. Manongko, Dr. Allen A. Ch. 2018. Green Marketing, Manado: Yayasan Makaria Waya.

Priansa, Donni Juni. 2017. Komunikasi Pemasaran Terpadu, Bandung: Pustaka Setia

Priansa, Donni Juni. 2017. Perilaku Konsumen Dalam Persaingan Bisnis Kontemporer, Bandung: Alfabeta.

Priyatno, Duwi SPSS 22 Pengolahan Data Terpraktis 2014, CV Andi Offest, Yogyakarta.

Setiadi, Nugroho J. 2013. Perilaku Konsumen: Perspektif Kontemporer Pada Motif, Tujuan dan Keinginan konsumen Edisi Revisi. Jakarta: Kencana.

Solomon, Michael R. 2013. Consumer Behaviour: Buying, Having and Being $10^{\text {th }}$ New Jersey: Pearson Pretince Hall.

Sugiyono, 2016 Metode Penelitian Kuantitatif, Kualitatif dan R\&D, Bandung: PT.Alfabet.

\section{Sumber Jurnal:}

Alfiani, Siti Rohana (2019) Pengaruh Desain Produk, Harga, Dan Promosi Terhadap Minat Beli Konsumen Produk Tunecca. Institut Agama Islam Negeri Ponogoro.

Anto, Ricki (2018) Pengaruh Store Atmosphere Dan Promosi Terhadap Minat Beli. Universitas Pasundan Bandung.

Anwari, Farah Ulfa (2018) Pengaruh Health Consciousness, Environmental Consciousness Dan Appearance Consciusness Terhadap Minat Beli Green Cosmetic \& Skincare Product Innisfree, Universitas Telkom Bandung.

Cahyowulan, Shinta Ayu Pratiwi (2018) Pengaruh Brand Ambassador Pada Minat Beli Produk Wrangler Dengan Citra Merek Sebagai Variabel Intervening. Universitas Sanata Dharma.

Hasanah, Uwatun (2007) Hubungan Antara Interaksi Teman Sebaya dan Konsep Diri dengan Perilaku Konsumtif pada Remaja Putri Skripsi thesis, Universitas Muhammadiyah Surakarta. 
Larasari, Ernie (2018) Pengaruh Brand Ambassador Dan Event Sponsorship Terhadap Purchase Intention Dengan Variabel Brand Image Sebagai Variabel Intervening, Universitas Sultan Ageng Tirtayasa.

Mardiani, Alifia Sarah etc (2018) Pengaruh Brand Ambassador Terhadap Minat Beli Konsumen Bandung Kunafe Cake, Universitas Telkom Bandung.

Novira, Silvia (2019) Analisis Faktor-Faktor Yang Mempengaruhi Keputusan Pembelian Konsumen Terhadap Produk Kosmetik Innisfree, Universitas Telkom Bandung.

\section{Sumber Website:}

Sales report Store Innisfree Central Park Mall

https://wartakota.tribunnews.com/2014/10/31/tren-gaya-hidup-konsumtif

https:/www.kompasiana.com/muharriatimuhar/5938fa7d3791c406cd325922/penampilan-adalah-

hal-terpenting-di-kalangan-para-pelajar-zaman-sekarang

https://www.npd.com/wps/portal/npd/us/news/press-releases/pr_120516/

https://katadata.co.id/berita/2019/04/10/tren-perawatan-kecantikan-naik-industri-kosmetik-dipatoktumbuh-9

https://www.uniquedailytips.com/2015/06/7-kosmetik-asli-indonesia.html?m=1

https://ekonomi.kompas.com/read/2018/08/20/161758326/perempuan-indonesia-pilih-produk-

kecantikan-dari-korea-bagaimana-dengan

www.innisfree.com

https://adityolaksono26.blogspot.com/2015/03pengertian-minat-beli-dan-faktor-faktor.html?m=1 